\title{
TABLET FORMULATION FROM MENIRAN (PHYLLANTHUS NIRURI L.) EXTRACT WITH DIRECT COMPRESSION METHOD
}

\author{
RESMI MUSTARICHIE ${ }^{1 *}$, DRADJAD PRIAMBODO ${ }^{2}$
}

1Faculty of Pharmacy, Universitas Padjadjaran, ²Department of Pharmaceutics (Apothecary Programme), Faculty of Pharmacy, Universitas Padjadjaran, Indonesia 45363

Email: resmi.mustarichie@unpad.ac.id

Received: 19 Apr 2018, Revised and Accepted: 24 May 2018

\begin{abstract}
Objective: The aim of the present study was to obtain an optimized formula of meniran (Phyllanthus niruri L.) extract tablets that fulfilled the requirements as a good pharmaceutical preparation based on Indonesian Pharmacopoeia IV and USP XVII.

Methods: P. niruri plant was collected and determined at the Laboratory of Plant Taxonomy, Universitas Padjadjaran. First performed phytochemical screening to determine the content of secondary metabolites. Then designed five kinds of tablet formulas of $P$. niruri extract using a direct compressed method with a variation of concentration of filler. Each formula contains a similar concentration of $P$. niruri extract as the active ingredient, avicel PH 102 and amprotab with varying concentrations as filler, talcum, and magnesium stearate as a lubricant and Aerosil@200 vv as an adsorbent. Tablet print mass and quality of the resulting tablets were then evaluated. Also, check whether the resulting tablets still contain $P$. niruri extract as the active substance or not.

Results: The results of phytochemical screening of simplicia and viscous plant extract showed the presence of alkaloids, polyphenols, tannins, and flavonoids as secondary metabolites. The five formulas made contain avicel PH 102 and amprotab as binders and crushers and the expected results such as shape and durability as desired. The results of examination of shrinkage rate of mass drying of tablet prints from the above five formulas indicated an increase of value from formula A (5.4609\%) to formula E (5.8600\%). This was because avicel PH 102 and amprotab had a considerable moisture content, so with the combination of both fillers could increase the water content from mass print tablets. Real density, compact density, and true density decreased from formula $\mathrm{A}$ to formula E. The amount of these densities were influenced by the shape and size of the particles. Flowability increased from formula A $\left(23.7124^{\circ}\right)$ to formula $\mathrm{E}\left(26.4210^{\circ}\right)$ whereas compressibility increased from formula A (21.7222\%) to formula E $(29,4121 \%)$. Flowability and compressibility increase might be due to the uniformity of the particle size between the amprotabs and the other additives which could cause electrical charges to the print mass affecting the speed and flow of the print mass. All quality testing results including Weight (mg), Thickness (mm), Diameter (mm), Hardness (N), Friability (\%) and Disintegration time (min.) had met the requirements. Thin Layer Chromatography showed that the resulting tablets still contain $P$. niruri extract as the active substance.
\end{abstract}

Conclusion:. Overall results showed that the formulation fulfilled the requirements as a good pharmaceutical preparation based on Indonesian Pharmacopoeia IV and USP XVII.

Keywords: Meniran, Phyllanthus niruri, Directly compressed tablet, Formulation, Avicel PH102

(C) 2018 The Authors. Published by Innovare Academic Sciences Pvt Ltd. This is an open access article under the CC BY license (http://creativecommons.org/licenses/by/4.0/) DOI: http://dx.doi.org/10.22159/ijap.2018v10i4.26795

\section{INTRODUCTION}

Utilization of plants as medicinal ingredients has long been known by people in Indonesia commonly known by the name of jamu (herbal medicine) [1]. One type of plant that has not been developed completely but has many uses, especially in traditional medicine is meniran (Phyllanthus niruri L.). Meniran is a wild plant, a season that grows in a moist and rocky place [2]. It was reported containing alkaloids, balsams, sterols, carbohydrates, glycosides, flavonoids, tannins, saponins, phlobatannins, resins and terpene in trace; while the essential elements are detected $\mathrm{Ca}, \mathrm{Na}, \mathrm{K}, \mathrm{P}, \mathrm{Mg}, \mathrm{Mn}, \mathrm{Fe}, \mathrm{Cu}$, and Zn. the plant is rich in various chemicals that differ from people. In Indonesia, meniran is widely used for the treatment of diuretics, renal impairment, mouth ulcers, antipyretics, malaria, antidiarrhoea, high blood pressure, menstrual cramps and bile disorders [4-6]. Choudhari et al. [7] developed a formula containing Andrographis paniculata, Momardica charantia, Phyllanthus niruri, Terminallia chebula, Glycyrrhiza glabra and Punica granatum for treatment and management of HIV-AIDS.

Based on the many benefits of meniran plants, one of them as anti diuretics, this article reports the formulation of the preparation of meniran extract in the form of tablets. If it is a tablet it will facilitate the use and transportation of the drug. Tablets are compact solid preparations, manufactured in a molded manner, in flat or circular tubes, either flat or convex surface, containing one or more drugs with or without additives. Additional substances used may serve as fillers, binders, lubricants, developing or crushing agents, or other suitable substances. Based on the method of making tablets can be classified into two, namely tablet prints and directly compressed tablets $[8,9]$. The tablets are made of medicinal materials and the fillers generally contain lactose and sucrose powder in various comparisons. The moist mass of the powder is pressed with low pressure into the molding hole. Then removed and allowed to dry. Tablet print is rather fragile, so be careful in packaging and distribution. On the other hand, the right-handed rock tablets have many advantages, especially in terms of durability and transportation. A direct compression method is a method of printing a medicinal substance or a mixture of medicinal substances and powdered auxiliary substances without going through the initial treatment process [10]. The direct compression method is the simplest method of making tablets compared with other tabletmaking methods, wherein this method there are only two processes: mixing materials and printing. The thing to note in this method is the use of appropriate auxiliary materials for the manufacture of direct compression [11, 12]. Furthermore, making tablets from plant extracts is usually constrained so that many plant extract products are marketed in liquid or capsule form. So far, preparation of compressed tablets from meniran extract has never been reported.

\section{MATERIALS AND METHODS}

\section{Material}

Dried meniran extract (PT Phytochemindo Reksa), Dragendorff, Mayer reagent, Lieberman-Buchard reagent and avicel magnesium powder PH 102, amprotab, talcum, magnesium stearate, green dye (PT Kimia Farma) and Aerosil® 200 vv (Degussa). 


\section{Equipment}

Analytical Scales (Mettler Toledo), Electronic scales (Nagata), Tablet-printing machines (E. Korsch), Moisture determination balance (Ohaus), Tapped density meter, Hardness tester (Erweka type TB-24), Friability tester, time test device crushed tablets (Erweka ZT-2).

\section{Methods}

\section{Collecting sample}

Meniran plant (P. niruri) and its dry extract obtained from PT. Phytochemindo Mutual, Gunung Putri, Bogor, West Java which was then determined in the Laboratory of Plant Taxonomy Department of Biology Faculty of Mathematics and Natural Sciences Universitas Padjadjaran.

\section{Phytochemical screening}

The phytochemical screening of meniran was performed to determine the content of the secondary metabolite compounds of the alkaloids, flavonoids, polyphenols, tannins, monoterpenoids, sesquiterpenoids, steroids, triterpenoids, quinones and saponins contained in the P. niruri simplicia by modification of the method of Farnsworth [13]

\section{Formulation and making meniran extract tablets}

The formulation of directly compressed tablets were designed with reference to existing libraries $[12,14]$. Made five kinds of tablet formulas extract meniran using direct compression method with variations of concentration of filler. The formula was a formula for one tablet so that this meniran extract tablet had a theoretical weight of $600 \mathrm{mg}$. In each laying process, we weighed a formula for 150 tablets. The steps taken in the process of making extract meniran tablets were as follows: first, all the tablet material sieved weighed and mixed until homogeneous. This homogeneous mass was then printed into a tablet using the E. Korsch tablet machine with punch 12 .

\section{Tablet print mass testing}

Tablet mass testing included drying drift, flowability, real density, compact density, true density, and compressibility. The procedure of determining these tests was based on Aulton method [15]. Loss of drying was analyzed using a drying shrinkage measuring tool, Moisture determination balance (Ohaus). Flowability was determined as follows, the tablet mass was placed in the funnel of the flow rate test vessel whose bottom was closed. The printed mass coming out of the apparatus was calculated in the flow velocity by calculating the time required by the amount of powder to descend through the test tool funnel by using the stopwatch from the beginning of the lower cap opening until all the granular mass flows out of the test apparatus. The granule deposits can be used to calculate the resting angle (flowability). Real density was determined by using pycnometers and liquids that did not dissolve granules ie liquid paraffin whereas true and compact densities were determined using measuring glass. Compressibility was calculated based on Carr index (compact density-real density)/compact density x $100 \%)$.

\section{Tablet quality testing}

Tablet quality testing includes weight uniformity, uniformity size, hardness, crispness and crumbling time. Weight uniformity test was based on Indonesian Pharmacopea III [8], uniformity size based on Indonesian Pharmacopea IV [9], Hardness was determined using Hardness tester. Friability was determined by friability tester in which tablets were weighed by approximately six point five grams, then incorporated into the tablet rigidity testers. The tool runs for four minutes at twenty-five lap speeds per minute. Tablets were still intact weighed, then calculated to lose weight. The weight loss allowed was not more than $0.8 \%$ USP XXVII [22].

\section{Qualitative test of tablet preparation with thin layer chromatography}

For thin layer chromatography, silica plate GF $\neg 254\urcorner$ was used with n-butanol, acetic acid and distilled water (4: 1: 5) as well as UV-254, UV366 $\mathrm{nm}$ and ammonia vapors.

\section{RESULTS AND DISCUSSION}

\section{Plant determination}

Determination conducted at the Laboratory of Taxonomy, Department of Biology Faculty of Mathematics and Natural Sciences University of Padjadjaran showed that the plants used in this formulation were meniran (Phyllanthus niruri L.) plants.

\section{Phytochemical screening}

The results of phytochemical screening of simplicia and viscous extract of $P$. niruri showed several classes of secondary metabolite compounds as seen in table 1. Nakweti et. al [16] mentioning that they found saponins in their Congo's $P$. niruri sample. Masruroh et. al [17], however, found saponin in their sample. Alegantina [18] reported that they found alkaloids, flavonoids, phenols, coumarins, tannins, terpenoids, and lignans (phyllanthin and hypophyllanthin). This difference in phytochemical screening results was most likely due to the different origin of the plant being examined.

Table 1: Phytochemical screening of simplicia and meniran viscous extract

\begin{tabular}{lll}
\hline Secondary metabolite & Simplicia & Viscous extract \\
\hline Alkaloids & + & + \\
Polyphenols & + & + \\
Tannin & + & + \\
Flavonoids & - & + \\
Mono and Sesquiterpene & - & - \\
Steroids and Terpenoids & - & - \\
Quinone & - & - \\
Saponins & & - \\
\hline
\end{tabular}

Notes: +: detected,-: not detected

\section{Formulation of meniran extract tablet}

The formulation of the extracted tablets was designed as shown in table 2. The production of tablets was divided into two, by granulation and direct compression methods. Meeus [18] reported differences from both methods. Suhery et. al [20] in their experiments stated that the results obtained showed that both methods produced the physical properties of a good tablet. However, the method of direct compression provides a disintegrating faster than with the wet granulation method. They applied statistical test using independent sampling $(\mathrm{P}<0.05)$ between the formula and the method of direct compression and wet granulation. Reiza [21] in his study on the comparison of the use of the wet and dry granulation method to the stability of the paracetamol active substance stated that on the use of dry granulation method in the direct compression method produced tablets that had better stability than tablets of wet granulation method. This possibly due to the process of wet granulation, paracetamol in the presence of water would be hydrolyzed to acetic acid and p-aminophenol. 
Table 2: Meniran extract tablets formula

\begin{tabular}{lllll}
\hline Formula & A (\%) & B (\%) & C (\%) & D (\%) \\
\hline Dried meniran extract & 44.67 & 44.67 & 44.67 & 44.67 \\
Avicel PH 102 & 50.73 & 47.50 & 45.00 & 42.50 \\
Amprotab & - & 3.23 & 5.73 & 8.23 \\
Talcum & 2.00 & 2.00 & 2.00 & 2.00 \\
Magnesium stearate & 2.00 & 2.00 & 2.00 & 2.00 \\
Aerosil@200 vv & 0.50 & 0.50 & 0.50 & 0.00 \\
Colouring substance & 0.10 & 0.10 & 0.10 & 0.50 \\
\hline
\end{tabular}

Notes: A, B, C, D, E: type of formula

On the determination of the formula of this meniran extract tablet, it was used avicel PH 102 and combined with the amprotab as filler, so it could form the size of the tablet as desired. The choice of avicel PH 102 was due to having a larger particle size compared to avicel $\mathrm{PH}$ 101, so the resulting flowing power was better than avicel PH 101 which had smaller particle size. In addition, avicel PH 102 was also widely used as a filler on the manufacture of tablets that use the method of direct compression. The use of avicel PH 102 on each tablet formula was a variation of five concentrations, i. e $40 \%$ $42,5 \%, 45 \%, 47,5 \%$ and 50,73\% in order to see avicel PH 102 effect on tablet preparation, avicel PH 102 could also act as a binder and crush in tablet formulations. In addition, a combination of Avicel PH 102 and amprotab was also made, which aimed to see the effect of the combination on the tablet preparations. In the manufacture of direct compression tablets, avicel PH102 is needed as a binder in the absence of granulation process.

As a lubricant in the formula of this meniran extract tablet was used talcum and magnesium stearate. The use of these two lubricants simultaneously was intended to provide a good lubricant effect on tablet formulas, which, as we had seen, had both advantages differed from one another. Talcum with a concentration of $1-5 \%$ could give good anti-adherent and glidant effect but had poor lubricant effect, while magnesium stearate with concentration $0,25-5 \%$ could have good lubricant effect but had less anti-adherent and glidant effect good. It was hoped that by combining the two lubricants could increase the mass flow of tablet prints upon entering the tablet mold, it could prevent the sticking of the print mass of tablets on punch and die and could make the dosage more glossy, thus increasing the aesthetic value of the tablet itself.

\section{The result of a mass print of tablet extract meniran}

Testing the print mass of the tablet was done before the tablet tableting process takes place. This test was intended to determine whether or not the print mass was printed into tablets, so this test could be used as a supporting factor to determine the quality of tablets to be printed. There were several requirements that must be met for the printing mass of the tablet to be printed properly, including drying shrinkage test, flowability, real density, compact density, true density and compressibility [8]. The results of tablet mass testing of each formula can be seen in table 3 .

The results of examination of shrinkage rate of mass drying of tablet prints from the above five formulas indicated an increase of value from formula A to formula B. This was because avicel PH 102 and amprotab had a considerable moisture content, so with the combination of both fillers could increase the water content from mass print tablets, so automatically the shrinkage rate of mass drying tablets print would increase as well. With the specified water content was expected to mass print tablets would not be too wet so that the mass of tablets prints could be hammered well into dosage tablets. In addition, the mass print tablets should not be too dry because the tablets would become brittle and could remove the binding capacity of the print mass that tends to form capping and lamination.

Table 3 Result of meniran mass testing print tablet

\begin{tabular}{|c|c|c|c|c|c|c|}
\hline Testing & Formula & $\mathbf{A}$ & B & $\mathbf{C}$ & D & $\mathbf{E}$ \\
\hline Loss on Drying (\%) & & 5.4609 & 5.8602 & 5.6497 & 5.6499 & 5.6800 \\
\hline Real density $(\mathrm{g} / \mathrm{ml})$ & & 0.6524 & 0.5323 & 0.5139 & 0.5070 & 0.5190 \\
\hline Compact density $(\mathrm{g} / \mathrm{ml}$ & & 0.8334 & 0.6947 & 0.7146 & 0.7215 & 0.7353 \\
\hline True density $(\mathrm{g} / \mathrm{ml})$ & & 1.6151 & 1,5236 & 1.4874 & 1.4773 & 1.4445 \\
\hline Flowability $\left({ }^{\circ}\right)$ & & 23.7124 & 26.2969 & 24.0748 & 24.8435 & 26.4210 \\
\hline Compressibility (\%) & & 21.7222 & 23.3818 & 28.0763 & 29,7210 & 29,4121 \\
\hline
\end{tabular}

Notes: A, B, C, D, E: type of formula

The amount of real density and incompressibility density was influenced by the shape and size of the particles. The density of spherical particles or spheres would be greater when compared to needle-shaped particles and stems. While the particle size was larger, it had a larger particle density value compared to small particles. Real density and compact density tests were performed to determine the compressibility of the print mass of tablets.

Tablet flowability testing was done without vibration. From the results of testing the flow power, the addition of amprotab into the formula could decrease the mass flow of print. This was due to the uniformity of the particle size between the amprotabs and the other additives which could cause electrical charges to the print mass affecting the speed and flow of the print mass.

\section{The result of quality testing of meniran extract tablet}

It is necessary to perform a quality test on tablets that have been produced. Testing the quality of the tablet includes uniformity of weight, uniformity of size, hardness, friability and crushed time [8, 9]. The results of these tests can be seen in table 4 . The results of testing the quality of tablets above showed that uniformity of weight, uniformity of size, friability and the crushed time of the five tablet formulas had met the requirements of Indonesian Pharmacopoeia IV [9] and USP XXVII [22].

\section{Tablet size uniformity}

The results of the uniformity test of the size indicate that the average thickness and diameter of the tablet meet the requirements of Indonesian Pharmacopoeia IV [9] where it was stated that the tablet diameter was not more than three times and not less than one-third of the thickness of the tablet (table 4).

\section{Tablet weight uniformity}

The charging volume used in this tablet printing process was set to a weight of $600 \mathrm{mg}$ by adjusting the bottom punch. Indonesian 
Pharmacopoeia III [8] stated that tablets weighing more than 300 mg should not deviate more than five percent, meaning that the weight of each tablet should be between $570 \mathrm{mg}$ to $630 \mathrm{mg}$. Thus the results of the study as listed in table 4 established requirements.

Table 4: Quality testing result of meniran extract tablet

\begin{tabular}{|c|c|c|c|c|c|}
\hline $\begin{array}{l}\text { Formula } \\
\text { Testing }\end{array}$ & $\mathbf{A}$ & B & $\mathbf{C}$ & D & $\mathbf{E}$ \\
\hline Weight (mg) & $601.4550 \pm 4.3182$ & $604.0400 \pm 6.7348$ & $606.8850 \pm 7.9118$ & $605.6250 \pm 8.5739$ & $601.7200 \pm 5.5539$ \\
\hline Thickness (mm) & $5.4015 \pm 0.0105$ & $5.3415 \pm 0.0589$ & $5.4215 \pm 0.0222$ & $5.1060 \pm 0.0466$ & $5.2930 \pm 0.0761$ \\
\hline Diameter (mm) & $12.1420 \pm 0.0068$ & $12.0995 \pm 0.0462$ & $12.1190 \pm 0.0479$ & $12.0825 \pm 0.0405$ & $12.1165 \pm 0.0299$ \\
\hline Hardness $(\mathrm{N})$ & $116.4500 \pm 7.5612$ & $112.5000 \pm 8.3291$ & $106.4250 \pm 6.3013$ & $109.9250 \pm 7.6129$ & $107.8750 \pm 7.6336$ \\
\hline Friability (\%) & $0.1579 \pm 0.0419$ & $0.2642 \pm 0.0156$ & $0.3522 \pm 0.0314$ & $0.4544 \pm 0.0346$ & $0.5881 \pm 0.0801$ \\
\hline Disintegration time (min.) & 02.20 & 02.35 & 04.12 & 05.45 & 07.10 \\
\hline
\end{tabular}

Notes: A, B, C, D, E: types of formula

\section{Tablet hardness}

From the results of hardness tablet testing using Erweka machine, the resulting average hardness ranging between 106-116 N. Hardness tablets were attempted to have a small range and made uniform, this was intended to minimize the influence of violence against time devastation and friability, so that the time difference was destroyed and the friability between one formula with the other could be regarded as the effect of different filler concentrations [8, 9].

\section{Friability}

From the results of testing the quality of tablets, the resulting average friability ranged from $0.1579-0.5881$. This value had met the requirements in accordance with USP XXVII [22], i. e the allowable weight loss was up to $0.8 \%$. It was found that the greater the concentration of avicel PH 102, the value of friability become decreased, this indicated that the greater the concentration of avicel PH 102, the resulting tablet was better and not fragile. This was possibly due to avicel $\mathrm{PH} 102$ had properties that made the tablet became not easily broken and hold scraping.

\section{Tablet disintegration time}

The disintegration timing test of the five tablet formulas of this meniran extract found that with the increase of the avicel concentration of $\mathrm{PH} 102$ in the formula could speed up the disintegration time of the tablets preparations. This was due to avicel PH 102 itself was as a destroyer or disintegrant. The crushed time of these five formulas ranges from two to seven and a half minutes. The value still meets the requirements stipulated in the Indonesian Pharmacopoeia IV [9], that was the time of disintegration should not be more than fifteen minutes.

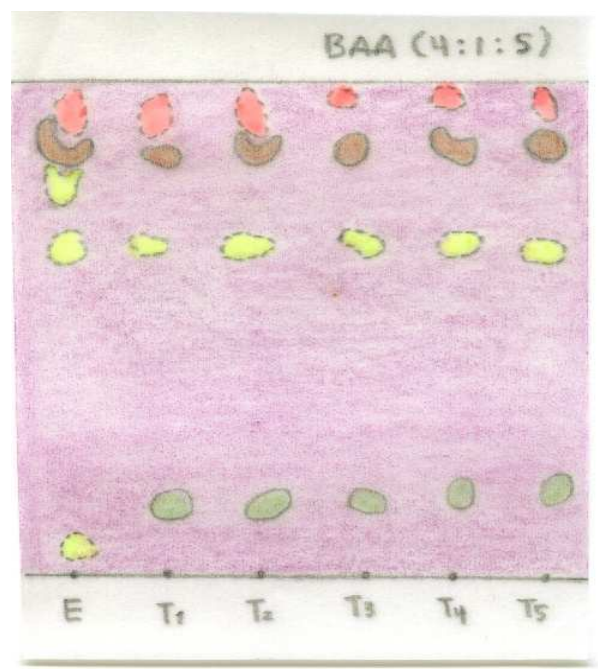

Fig. 1: Thin layer chromatography results from extracts and meniran tablets, Notes: $E$ (Ekstrak meniran), $T_{1}$ (Formula A), $T_{2}$ (Formula B), $T_{3}$ (Formula C), $T_{4}$ (Formula D) and $T_{5}$ (Formula E)

\section{Qualitative test of meniran extract tablet}

Qualitative test was performed on extract and fifth formulas of meniran extract tablets using thin layer chromatography (TLC) method. This test aimed to be able to identify the uniformity of the compound content contained in meniran thick extract and the five formulas of meniran extract tablets. This was indicated by spots that have the same $\mathrm{Rf}$ value. It was also intended to identify the compounds of quercetin and nirurin, which were thought to have a diuretic effect [23]. The stationary phase of TLC was silica gel GF254 plate, the eluent was n-butanol: acetate: water $(4: 1: 5)$ and spotting viewer was UV 254 and $366 \mathrm{~nm}$, and ammonia vapor. Chromatographic results can be seen in the fig. 1 .

\section{Statistical analysis}

The statistical analysis was guided by Sudjana [24]. From the result of data analysis using Perfect Random Design, with $95 \%$ confidence gave result $\mathrm{F}_{\text {count }}$ bigger than $\mathrm{F}$ table $(43,4934>3,48)$. This indicated that the five variations in avicel concentration of PH 102 had the significantly different effect on tablet disintegration time. At the concentration of avicel PH $10240 \%$ gave the mean of the longest destroyed time of 7.27 min, while at concentration avicel PH 102 $50,73 \%$ gave mean of fastest crushed time that is 1,92 minute. To find out which concentration was most influential to tablet disintegration time than Newman-Keuls test was carried out. Newman-Keuls test results showed that not all treatments give significant difference $(\alpha=0.05)$, there was a difference between the formulas 5 and 2, 5 and 1, 4 and 2, 4 and 1, 3 and 1. From these results it was concluded that the concentration of avicel PH $10240 \%$ gave significant difference with avicel concentration of PH 102 $47,5 \%$, avicel concentration of $\mathrm{PH} 10240 \%$ gave significant difference with avicel concentration PH 102 50,73\%, avicel concentration PH 102 42,5\% gave significant difference with avicel concentration of $\mathrm{PH} 102$ 47,5\%, avicel concentration of PH 102 $42,5 \%$ gave significant difference with avicel concentration of $\mathrm{PH}$ 102 50,73\%, avicel concentration of PH 102 45\% gave significant difference with avicel PH concentration $10250.73 \%$. While the other comparison did not make a significant difference.

Preparation of tablets directly compressed tablet from the meniran extract has not yet investigated, but the tendency to make tablets from plant extracts that efficacy must be recognized has begun many in the interest of researchers. Duraisankar and Ravichandran [25] stated that the antipyretic effect of the aqueous extract of polyherbal (Sweertia chirata, Solanum xanthocarpum, Tinospora cortifolia, Operculina turpethum, Cyperus rotuntus, picrorrhiza curroa, Melia azadirachta $)$ was comparable to that of paracetamol $\left(150 \mathrm{mg} \mathrm{kg}^{-1}\right.$ body weight p. o), a standard antipyretic agent. Muthiah [26], for example, reportedly prepared a chewed tablet formulation of dewandaru leaf extract (Eugenia uniflora L.) with a combination of mannitol-lactose filler. Dewandaru leaves are said to be efficacious as antibacterial, anti-free radical, and anti-diarrhea. Preparation of tablets from tapak dara leaf extract that is thought to be efficacious as an anti-cancer drug because it contains vinblastine alkaloids and vincristine has been studied as a result of thesis [27]. Hussein [28] claimed have made a novel retardant by formulating sustained release tablet of Pentoxifylline using Okra (Abelmoschus esculentus) 
extract. One of the researchers [29] has also been used direct compression method for the manufacture of tablets from Andrographis paniculata leaf extract but this researcher uses a different formula. On the other hand, a wet granulation method for making tablets from plant extracts has also been reported [30].

\section{CONCLUSION}

Based on the results of research that has been done, it can be concluded that the $P$. nirusi extract as one of the natural ingredients diuretic can be made into a tablet that meets the requirements as a pharmaceutical preparation. Based on the results of the print mass testing and the quality of the tablets that have been performed, the tablets have uniformity, size, hardness, friability and crushed time meets the requirements set forth in the Indonesian Pharmacopoeia IV and USP XXVII. It is found that the greater the concentration of avicel PH 102 will decrease the value of friability tablets, but also the greater the concentration of avicel PH 102 will speed up the destruction time of the tablet. It is also found based on the results of qualitative tests using thin layer chromatography that the nutritious substances extract is still present in the tablets after going through the stages of formulation.

\section{ACKNOWLEDGMENT}

We thank Anggi Agustria Mahardhika for technical support.

\section{AUTHORS CONTRIBUTIONS}

All the author have contributed equally

\section{CONFLICT OF INTERESTS}

No conflict of interests between authors

\section{REFERENCES}

1. Masli N. Turning the herbal medicine jamu into green energy and savings; $2015 . \quad$ Available from: https://www.lifegate.com/people/news/jamu-turning-wasteinto-fuel. [Last accessed on 16 Apr 2018]

2. Dalimartha S. Atlas of Indonesian Medicinal Plants (Indonesian: Atlas Tumbuhan Obat Indonesia). 2nd Ed. Jakarta: Trubus Agriwidya; 2000. p. 136.

3. Samali A, Florence DT, Odeniran OA, Cordelia ON. Evaluation of chemical constituents of phyllanthus niruri. Afr J Pharm Pharmacol 2012;6:125-8.

4. Sastramidjojo S. Original Indonesian medicine (Indonesian: Obat Asli Indonesia), Jakarta: Pustaka Rakyat; 1962. p. 182-3, 639-43.

5. Rivai H, Septika R, Boestari A. Characterization of herbal meniran extract (Phyllanthus niruri Linn) with fluorescence analysis (Indonesian: Karakterisasi ekstrak herbal meniran (Phyllanthus niruri Linn) dengan analisa fluoresensi. J Farmasi Higea 2013;5:15-22.

6. Subarnas A, Sidik S. Phyllanthus niruri Linn., Chemistry, Pharmacology and its use as a traditional medicine (Indonesian: Phyllanthus niruri Linn., Kimia, Farmakologi dan penggunaannya sebagai obat tradisional), Warta Tumbuhan Obat Indonesia; 1993

7. Choudhari AB, Rangari VD, Darvekar VM. Formulation development for treatment and management of HIV-AIDS. Int J Pharm Pharm Sci 2011;3:105-8.

8. Departemen Kesehatan RI, Farmakope Indonesia, Edisi III. Jakarta: Departemen Kesehatan Republik Indonesia; 1979. p. 6-7, 9, 354, 591-2.

9. Departemen Kesehatan RI. Farmakope Indonesia, Edisi IV, Jakarta: Departemen Kesehatan Republik Indonesia; 1995. p. 4-7, 515-6, 771-2.

10. Ansel HC. Ansel pharmaceutical drug forms and drug delivery system (Indonesian: Pengantar Bentuk Sediaan Farmasi), Translated by Farida Ibrahim, Edisi IV, Jakarta: UI-Press; 2008. p. 251-71.

11. Lieberman HA. Pharmaceutical Dosage Form: Tablet. Vol. 1. 2nd Edition. New York: Marcel Dekker Inc; 1989. p. 195-9.
12. Fuhrman C. Ansel's pharmaceutical dosage forms and drug delivery systems. $8^{\text {th }}$ Edition. Am J Pharm Educ 2006;70:71.

13. Farnsworth NR. Biological and phytochemical screening of plants. J Pharm Sci 1966;53:243-51, 264-5.

14. Suhery WN, Fernando A, Giovanni B. Comparison of wet granulation and direct compression methods on physical properties and disintegration time of orally disintegrating tablet of piroxicam. J Sains Farmasi Klinis 2016;2:138-44.

15. Aulton ME. Pharmaceutics: the science of dosage form design, churchill livingstone Inc, New York; 1988. p. 247-253, 304-321, 600-615, 647-67.

16. Nakweti RK, Ndiku SL, Doumas P, Nkung MHS, Baissac Y, Kanyanga $\mathrm{RC}$, et al. Phytochemical analysis of Phyllanthus niruri L. (Phyllanthaceae) extracts collected in four geographical areas in the democratic republic of the congo. Afr J Plant Sci 2013;7:9-20.

17. Masruroh E, Tukiran T, Suyatno S, Hidayati N. Preliminary phytochemical analysis of meniran (Phyllanthus niruri L), prosiding seminar nasional kimia, ISBN: 978-602-0951-00-3, Jurusan Kimia FMIPA Universitas Negeri Surabaya; 2014. p. B-252-B-258.

18. Alegantina S, Setyorini HA, Triwahyuni T. Quality assay and quantitative determination of Phyllanthus from an ethanolic extract in Meniran herbs (Phyllanthus niruri Linn). Bul Penelit Kesehat 2015;43:11-6.

19. Meeus L. Direct compression versus granulation. Available from: http://www.pharmtech.com/direct-compression-versusgranulation. [Last accessed on 18 Apr 2018]

20. Suhery WN, Fernando A, Giovanni B. Comparison of wet granulation and direct compression methods on physical properties and disintegration time of orally disintegrating tablet of piroxicam. J Sains Farmasi Klinis 2016;2:138-44.

21. Rieza Z. Comparison of the use of wet granulation method and dying granulation on the stability of active tablet paracetamol (Indonesian: Perbandingan penggunaaan metode granulasi basah dan kering terhadap stabilitas zat akrif parasetamol). Thesis. Indonesia: Fakultas Farmasi, Universitas Muhammadiyah Surakarta; 2010

22. United States Pharmacopeia and National Formulary (USP27NF22) Rockville: United State Pharmacopeial Inc; 2004. p. 2271, 2272, 2302, 2621, 2622.

23. Kardinan A. Meniran natural body endurance enhancer (Indonesian: Meniran Penambah Daya Tahan Tubuh Alami) Bogor: Agromedia Pustaka; 2004. p. 1, 6-13.

24. Sudjana MA. Design and experimental analysis (Indonesian: Desain dan Analisis Eksperimen). 2ndEd. Bandung: Tarsito 1994. p. 34-9.

25. Duraisankar M, Ravichandran V. Antipyretic potential of polyherbal ayurvedic products. Asian J Pharm Clin Res 2012;5:146-50.

26. Muthiah D. Formulation of a chewable tablet from dewandaru leaf extract (Eugenia uniflora L.) with a combination of mannitol-lactose as fillers (Indonesian: Formulasi tablet kunyah ekstrak daun dewandaru (Eugenia uniflora L.) dengan kombinasi pengisi manitol-laktosa). Thesis. Indonesia: Fakultas Farmasi, Universitas Muhammadiyah Surakarta); 2008.

27. Dinata LPD. Formulation of tapak dara (Catharanthus roseus (L) G. Don) extract with gelatin and gummi arabicum binders on various concentrations (Indonesian: Formulasi tablet ekstrak herba tapak dara (Catharantus roseus (L) G. Don) dengan bahan pengikat gelatin dan gom arab pada berbagai konsentrasi). Thesis Indonesia: Fakultas Farmasi Universitas Muhammadiyah Surakarta; 2009.

28. Hussein AH. Formulation and evaluation of sustained release tablets of Pentoxifylline using Okra extract. Int J Pharm Pharm Sci 2014;7:204-8.

29. Kusumawat L. Tablets formulation of sambiloto (Andrographis paniculata $\mathrm{N}$.) leaves extract by direct compressed with mannitolsorbitol as fillers materials. Galenika J Pharm 2015;1:73-8.

30. Fitri YA, Priambodo D, Lestari K. The tablet formulation of nutmeg extract (Myristica fragrans Houtt.) free of myristin and safrol by wet granulation method (Indonesian: Formulasi tablet dari ekstrak biji pala (Myristica fragrans Houtt.) bebas miristin dan safrol dengan metode granulasi basah). Indonesian J Pharm Sci Technol 2016;5:8-22. 